\title{
Amorphous calcium phosphate NPs-mediated macrophage response and modulate BMSCs osteogenesis
}

\section{Liangjiao Chen}

Chinese PLA General Hospital

\section{Pengyan Qiao}

Chinese PLA General Hospital

Hongcheng Liu ( $\sim$ liu-hc301@hotmail.com )

Chinese PLA General Hospital

\section{Longquan Shao}

Southern Medical University

\section{Research}

Keywords: ACP nanoparticles, macrophage polarization, cytokine, autophagy, osteogenic differentiation

Posted Date: February 24th, 2020

DOI: https://doi.org/10.21203/rs.2.24287/v1

License: (a) (i) This work is licensed under a Creative Commons Attribution 4.0 International License. Read Full License 


\section{Abstract}

Objective:

To evaluate macrophage responses to ACP nanoparticles and the effect of ACP nanoparticle/macrophage-modulated environments on the osteogenic ability of BMSCs.

\section{Materials and methods:}

Macrophage polarization and cytokine expression were determined by SEM, cytoskeletal staining, RT-PCR and ELISA. ROS and autophagy expression were evaluated. TMT ${ }^{\mathrm{TM}}$ quantitative protein analysis was used to evaluate protein expression. BMSC osteogenic differentiation was detected by ALP staining, Alizarin Red solution staining and RT-PCR.

\section{Results}

ACP nanoparticles changed macrophage morphology and polarized into M1 type. ACP nanoparticles promoted autophagy and induced the production of ROS at high concentrations. ACP nanoparticle/macrophage-modulated environments weakened the osteogenic ability of BMSCs.

\section{Conclusion}

ACP nanoparticles polarize macrophages into the M1 phenotype. ACP nanoparticle/macrophagemodulated environments weaken the osteogenic ability of BMSCs.

\section{Introduction}

Calcium phosphate $(\mathrm{CaP})$ is often used as a bone substitute or coating material. It has been proven safe and biocompatible. However, $\mathrm{CaP}$ ceramics also have properties that induce an inflammatory cellular response. The inflammatory response is influenced by physicochemical properties, such as crystallinity, solubility, and surface area. Particle materials implanted into local tissue will cause an inflammatory response. Macrophages are the primary effector cells, and they release a variety of cytokines, such as TNF- a, IL-6 and IL-10. These signalling cytokines play an important role in cellular processes that may be related to osteogenesis. Monocytes/macrophages first recognize and attack foreign objects, thus playing an important role in innate immunity. Macrophages can be polarized into the M1 or M2 phenotype by different biomaterials. M1 macrophages secrete cytokines to promote inflammation, whereas M2 macrophages produce anti-inflammatory mediators. Rao. et al reported that a higher proportion of M1 macrophages than M2 macrophages is closely related to aseptic inflammation, which suggests that although the coating materials or NPs may be compatible with the host, the chronic foreign body reaction evocable by macrophages will cause aseptic inflammation. Growing evidence supports amorphous CaP (ACP) nanoparticles (NPs) mediating the growth of apatite in vivo and in vitro. In oral medicine, ACP is a promising biomimetic material for dental remineralization. ACP NPs promote dentine mineralization. It has also been reported that the mixture of nanoscale ACP weakens the inflammatory response induced 
by poly (L-lactic acid) material. However, the direct influence of ACP on macrophages remains unclear because most previous studies focused on the biocompatibility and application of the particles. The aim of the current study was to examine whether ACP induces a change in macrophage polarization and the cytokine secretion pattern of macrophages, affects intracellular homeostasis and subsequently affects the osteoblastic differentiation of MSCs.

\section{Materials And Methods}

\subsection{Material preparation and characterization}

ACP NPs were purchased from Sigma-Aldrich (Sigma, USA, 693871). Scanning electron microscopy (SEM; Nova Nano SEM 430, FEl, Finland) was used to observe surface morphologies, and elemental analysis was performed using energy-dispersive X-ray spectroscopy (EDS; DX-4 system, EDAX, USA). Xray diffraction (XRD; Geigerflex, Rigaku Co, Japan) was used to analyse crystal structures, and diffraction patterns were measured in the 2 theta range from $10^{\circ}$ to $80^{\circ}$ using monochromatic $\mathrm{Cu}$ Ka radiation. NP sizes were determined using an NP size analyser. To exclude contamination, endotoxin levels were measured with an E-Toxate Kit (Sigma, St. Louis, USA). Aliquots of the NPs were dispensed into endotoxin-free water, then incubated with Limulus polyphemus for $1 \mathrm{~h}$ at $37^{\circ} \mathrm{C}$. Gel formation was evaluated to test the endotoxin levels.

\subsection{Cell morphology and viability}

Mouse RAW 264.7 macrophages (American Type Culture Collection (ATCC), TIB71, MD, USA) were cultured according to the methods recommended by the ATCC. The cells were cultured in Dulbecco's modified Eagle's medium (DMEM) supplemented with 10\% foetal calf serum (Life Technologies, USA), glutamine $(2 \mathrm{mM})$, penicillin $(5000 \mathrm{U} / \mathrm{mL})$ and streptomycin $(25 \mu \mathrm{g} / \mathrm{mL})$ at $37^{\circ} \mathrm{C}$ under a saturated $5 \%$ $\mathrm{CO}_{2} / 95 \%$ air atmosphere.

RAW 264.7 cells were seeded on slides. Experimental groups were cultured with $50 \mu \mathrm{g} / \mathrm{mL}, 100 \mu \mathrm{g} / \mathrm{mL}$, and $150 \mu \mathrm{g} / \mathrm{mL}$ NPs. Negative controls, without NPs, were also examined. Cells were cultured in DMEM with $1 \mu \mathrm{g} / \mathrm{mL}$ lipopolysaccharide (LPS, Sigma St. Louis, USA) were used as positive controls to evaluate cell morphology. After $24 \mathrm{~h}$, cells were fixed with $4 \%$ glutaraldehyde for $15 \mathrm{~min}$ and then gradient dehydrated by $30 \%, 50 \%, 75 \%, 80 \%, 95 \%$, and $100 \%$ alcohol for 15 min at each step. SEM observation of cell morphology occurred after natural air drying.

For fluorescence microscopy analysis, the fixed cells were permeabilized using $0.1 \%$ Triton for 5 min. Then, Alexa Fluor ${ }^{\circledR}$ 568-conjugated phalloidin (1:250 dilutions) was added to stain cytoskeletons for $1 \mathrm{~h}$ at $37^{\circ} \mathrm{C}$. Then, 4',6-diamidino-2-phenylindole (DAPI) was added to stain nuclei for $10 \mathrm{~min}$. After sample incubation in the dark, images were captured using a confocal microscope (TCS SP5, Leica Microsystem, Solms, Germany). 
Cell proliferation rates were determined by Cell Counting Kit-8 (CCK-8) assay. For the positive control group, RAW cells were culture with a $0.64 \%$ phenol solution. The experimental groups and negative/positive control groups were cultured for $24 \mathrm{~h}$ and $48 \mathrm{~h}$. Following the kit instructions, a ratio of one to ten CCK-8 solution was added to each culture well and then incubated for $1-4 \mathrm{~h}$, and the absorbance at $450 \mathrm{~nm}$ was determined with a microplate reader (Bio-Rad, California, USA). The cell viability percentage was calculated based on the optical density (OD) values.

Apoptosis levels were evaluated by flow cytometry (FCM) using an FITC Annexin V Apoptosis Detection Kit (Dojindo, Japan) according to the instructions. Briefly, cells were stained with FITC-conjugated annexin $\mathrm{V}$ and propidium iodide (PI). Viable cells were not stained with annexin V and PI. Early apoptotic cells were stained with annexin $\mathrm{V}$ but not PI. Late apoptotic and/or necrotic cells were stained with both annexin V and PI. Data were acquired on a FACS Calibur (BD Biosciences, San Jose, USA) flow cytometer using Cell Quest software (BD Biosciences) and analysed using Flow Jo software.

\subsection{Polarization of macrophages and inflammatory response}

RAW 264.7 cells were seeded in 6-well plates at a density of $2.5 \times 10^{5}$ cells per well. After $24 \mathrm{~h}$ of incubation, the cells were cultured with $50 \mu \mathrm{g} / \mathrm{mL}, 100 \mu \mathrm{g} / \mathrm{mL}$, and $150 \mu \mathrm{g} / \mathrm{mL}$ ACP NPs for $1 \mathrm{~d}$. Positive control groups were treated with $1 \mu \mathrm{g} / \mathrm{ml}$ LPS. Total RNA was isolated from cells using RNAiso Plus (TaKaRa Biotechnology, Japan). A total of $500 \mathrm{ng}$ of RNA from each sample was subjected to reverse transcription with Oligo dT as the first-strand cDNA primer (TaKaRa Biotechnology, Japan). RT-PCR was performed to assess the expression levels of CD206, CD163, CD86 and CCR7. Levels of the inflammatory factors TNF- $\alpha$, IL-1 $\beta$ and IL-10 were also evaluated (TB green ${ }^{\text {TM }}$ Premi Ex Taq ${ }^{\text {TM }}$ II, TaKaRa Biotechnology, Japan).

The protein levels of TNF-a, IL-1 $\beta$ and IL-10 were determined by enzyme-linked immunosorbent assays (ELISAs). Medium was collected after incubation for $24 \mathrm{~h}$. The concentrations of TNF-a, IL-1 $\beta$ and IL-10 were measured using commercial ELISA kits. The sensitivity of TNF-a was $0.78 \mathrm{ng} / \mathrm{mL}$. The sensitivities of IL-1 $\beta$ and IL-10 were $31.3 \mathrm{pg} / \mathrm{mL}$ (BioLegend, San Diego, USA). According to the manufacturer's instructions, cytokine concentrations were determined by measuring the OD at $450 \mathrm{~nm}$ (PerkinElmer 2030, PerkinElmer, Germany). The secreted cytokine content was calculated using standard curves that were constructed for each cytokine.

\subsection{ROS production and activation of autophagy}

To explore the oxidative stress response of ACP in RAW 264.7 cells, we used a reactive oxygen species (ROS) test kit (Nanjing Jian Cheng Biology Engineering Institute, Jiangsu, China) to test superoxide dismutase (SOD) activity. RAW 264.7 cells were cultured with or without ACP in 6-well plates for $3 \mathrm{~h}$ and $12 \mathrm{~h}$. After incubation, the media were removed, and the cells were washed with phosphate-buffered saline (PBS). Then, the plate was incubated with 2',7'-dichlorodihydrofluorescein diacetate (DCFDA) solution for $45 \mathrm{~min}$ at $37^{\circ} \mathrm{C}$ in the dark. FCM was used to evaluate the ROS content. The expression 
levels of autophagy pathway-related molecules were determined after incubation for $6 \mathrm{~h}$ and $12 \mathrm{~h}$. The expression levels of LC3A/B, p62, Beclin-1 (Abcam, USA) and GAPDH were assessed by Western blotting.

\subsection{Protein expression changes in RAW 264.7}

The protein level of RAW 264.7 cells treated with $100 \mu \mathrm{g} / \mathrm{mL}$ ACP was determined by TMT $^{\mathrm{TM}}$ quantitative protein analysis (Tandem Mass $\operatorname{Tag}^{\mathrm{TM}}$ ). The A group was the control group. The $\mathrm{B}$ group was treated with $100 \mu \mathrm{g} / \mathrm{mL}$ ACP for $24 \mathrm{~h}$.

\subsection{Cell morphology and proliferation of BMSCs}

Balb/c bone marrow stem cells (BMSCs, MUCMX-01001, Cyagen Biosciences Inc., USA) were cultured according to the methods recommended by the instructions. In addition, $50 \mu \mathrm{g} / \mathrm{mL}, 100 \mu \mathrm{g} / \mathrm{mL}$, and $150 \mu \mathrm{g} / \mathrm{mL}$ NPs were cultured with BMSCs for $24 \mathrm{~h}$. After $24 \mathrm{~h}$, the morphology of cells was determined by cytoskeletal staining. The proliferation of cells was analysed by CCK-8 assay.

\subsection{Effect of ACP nanoparticle/macrophage-modulated environment on osteogenic differentiation of BMSCs}

To investigate the effect of ACP NPs/macrophage modulation of the osteo-immune environment on the osteogenic potential of BMSCs. Medium of RAW264.7 cells cultured with $100 \mu \mathrm{g} / \mathrm{mL}$ ACP NPs for $24 \mathrm{~h}$ was collected as conditioned medium. Osteogenic components ( $2 \mathrm{mM} \beta$-glycerophosphate, $100 \mathrm{mM}_{\mathrm{L}^{-}}$ ascorbic acid 2-phosphate, and 10 nM dexamethasone, Sigma, Aldrich, USA) were used as basic medium. The conditioned medium was applied to stimulate BMSCs. The BMSCs were also stimulated by $100 \mu \mathrm{g} / \mathrm{mL}$ ACP NPs and conditioned medium combined with $100 \mu \mathrm{g} / \mathrm{mL}$ ACP NPs. A control group was cultured with only osteogenic components. Alkaline phosphatase (ALP) staining was used to analyse ALP activity after 1, 3 and $7 \mathrm{~d}$ of cultivation. Alizarin Red $\mathrm{S}$ staining was used to visualize the mineralization nodules generated by BMSCs grown in a 48-well plate for $7 \mathrm{~d}$ and $14 \mathrm{~d}$. The cells were fixed with $4 \%$ paraformaldehyde for 15 min. After fixation, the cells were stained using $2 \%$ Alizarin Red Solution for $10 \mathrm{~min}$. Images were captured using a light microscope. The expression levels of BSP, OSX, OPN, RUNX-2 and OC were determined by RT-PCR after $7 \mathrm{~d}$.

\subsection{Statistical analyses}

One-way ANOVA with the least significant difference (LSD) test was used to analyse data that passed a normality test. Dunnett's test was used for abnormal distributions. All analyses were conducted using SPSS 17.0 software (SPSS Inc., Chicago, IL, USA). P values $<0.05$ were considered significant.

\section{Results}

\subsection{Characterization of ACP NPs}

SEM images revealed that the ACP NPs had an amorphous morphology. EDS analyses detected Ca, $\mathrm{P}$ and $\mathrm{O}$ corresponding to $\mathrm{Ca}_{3}\left(\mathrm{PO}_{4}\right)_{2}$ (Supplementary Fig. 1.A, B). The corresponding peaks were matched 
with standard peaks (Supplementary Fig. 1.C). Results from a NP size analyser showed that the diameter of ACP powder particles was approximately $150 \mathrm{~nm}$ (d50 values, Supplementary Fig. 1.D). Endotoxin levels were below $0.05 \mathrm{EU} / \mathrm{mL}$ because there was no gel formation in the samples.

\subsection{Cell morphology and viability}

SEM images showed that cell morphologies changed after NP exposure. The control group cells were round, and their edges were smooth. After exposure to $50 \mu \mathrm{g} / \mathrm{mL}$ ACP NPs, the cells were still round, but their edges spread slightly. Treatment with $100 \mu \mathrm{g} / \mathrm{mL}$ or $150 \mu \mathrm{g} / \mathrm{mL}$ ACP NPs resulted in tiny pseudopodia protruding from the edges of the cells (Fig. 1). Cytoskeletal staining revealed that ACP NP exposure changed the cell morphology. Treatment with $50 \mu \mathrm{g} / \mathrm{mL}$ ACP NPs did not change cytoskeletal activity. RAW 274.7 cells were spread by exposure to 100 and $150 \mu \mathrm{g} / \mathrm{mL}$ ACP NPs (Fig. 2).

Greater than $95 \%$ or $100 \%$ (before and after powder exposure) cell proliferation rates were observed in the test groups. No cytotoxicity was detected after exposure to ACP NPs for 24 and $48 \mathrm{~h}$ (Fig. 3). No obvious apoptosis was observed in the FCM analysis after $24 \mathrm{~h}$ and $48 \mathrm{~h}$ of cultivation (Fig. 4).

\subsection{Polarization of macrophages and inflammatory response}

The expression of the M2 macrophage cell surface markers CD206 and CD163 was significantly downregulated under ACP NP exposure. The M1 macrophage cell surface marker CD86 was upregulated significantly, and CCR7 was upregulated in the $50 \mu \mathrm{g} / \mathrm{mL}$ and $150 \mu \mathrm{g} / \mathrm{mL}$ groups. CCR7 was downregulated in the $100 \mu \mathrm{g} / \mathrm{mL}$ group, but this downregulation was not statistically significant. Expression of TNF-a was slightly downregulated in the $50 \mu \mathrm{g} / \mathrm{mL}$ and $100 \mu \mathrm{g} / \mathrm{mL}$ groups and displayed no significant expression change in the $150 \mu \mathrm{g} / \mathrm{mL}$ group. The pro-inflammatory cytokine IL-1 $\beta$ was significantly upregulated. There was no significant change in IL-10 expression level.

Based on RT-qPCR results, ELISAs were used to determine the protein levels of TNF-a, IL-1 $\beta$ and IL-10. The TNF- $a$ concentrations were not increased in the ACP NP groups compared with the control group $(\mathrm{P}<$ 0.05). The same trends were observed when mRNA expression was analysed. The concentrations of IL-1 $\beta$ were significantly increased in the ACP NP groups compared to the control group $(P<0.05)$. The concentration of IL-10 was not increased or decreased significantly in all ACP NP groups (Fig. 5).

\subsection{Changes in homeostasis in RAW 264.7 cells}

FCM was used to evaluate ROS levels. The results show that $50 \mu \mathrm{g} / \mathrm{mL}$ and $100 \mu \mathrm{g} / \mathrm{mL}$ ACP NPs do not increase ROS production from negative control group ROS levels. ROS production increased with exposure to high concentrations of ACP.

ACP NPs changed the autophagy level of RAW 264.7 cells. ACP NP exposure changed the expression level of p62 and LC3. P62 expression was downregulated with increasing concentrations. The LC3I to LC3II ratio decreased at 150ug/ml. (Fig. 6). 


\subsection{Protein expression of RAW264.7 cells treated with ACP NPs.}

In this study, the protein level of RAW 264.7 cells treated with $100 \mu \mathrm{g} / \mathrm{mL}$ ACP NPs was determined. Quantitative protein analysis showed that 7633 proteins were quantified for three replicates. Significant up/downregulation between groups was determined by a mean fold change $>1.2$ with a $P$ value $>0.05$. In total, 151 proteins were significantly up- or downregulated after exposure to ACP NPs. Specifically, 106 proteins were upregulated, and 45 proteins were downregulated (Fig. 7). Heat map of protein expression) The detail information of differentially expressed proteins were listed (supplement Fig. 2). Specifically, growth factors of protein kinase $\mathrm{C}$ and bone morphogenetic protein receptor type- $1 \mathrm{~A}$ were upregulated. Interleukin-1 receptor-associated kinase-like 2 was upregulated. However, IL-17 receptor A was downregulated. According to an annotation of all identified proteins and a screening of differentially expressed proteins, we conducted an enrichment analysis of functional annotation types such as gene ontology (GO) terms, Kyoto Encyclopedia of Genes and Genomes (KEGG) terms and protein domain to determine whether the differentially expressed proteins were significantly enriched in some functional types. For P values obtained by Fisher's exact test (Fisher's exact test), a negative logarithm $(-\log 10)$ conversion was performed. In other words, the larger the converted value was, the more significant the enrichment of the corresponding function type. The results showed that upregulated proteins were enriched in response to calcium ions and metal ions. The associated molecular function is also relevant to calcium ion binding (Supplemental Fig. 3).

\subsection{Morphology and proliferation on BMSCs}

Cytoskeletal staining results showed that the morphology of BMSCs changed. BMSCs became round, and cell division was accelerated after ACP NP exposure (Fig. 8). The CCK-8 results also showed that nCap promotes cell proliferation(Fig. 3).

\subsection{Osteogenic differentiation of BMSCs}

The ALP staining results showed that the conditioned medium decreased the ALP activity at days 1,3 and 7. The conditioned medium combined with $100 \mu \mathrm{g} / \mathrm{mL}$ ACP NPs decreased ALP activity compared with $100 \mu \mathrm{g} / \mathrm{mL}$ ACP NPs alone at $1 \mathrm{~d}$. There was no difference at $3 \mathrm{~d}$ and $7 \mathrm{~d}$ (Fig. 9). Alizarin Red staining showed a low level of mineralization in the conditioned medium group at $7 \mathrm{~d}$ and $14 \mathrm{~d}$. The $100 \mu \mathrm{g} / \mathrm{mL}$ ACP NPs combined with conditioned medium showed a lower level of mineralization than the $100 \mu \mathrm{g} / \mathrm{mL}$ ACP NP group (Fig. 9). RT-PCR results revealed that the osteogenic genes BSP, OPN and OSX were upregulated in the $100 \mu \mathrm{g} / \mathrm{ml} \mathrm{ACP}$ group. Compared with the control group, the conditioned medium (CM) group showed decreased BSP, OSX and OC expression. Compared with the $100 \mu \mathrm{g} / \mathrm{ml}$ ACP group, the $\mathrm{CM}$ and $100 \mu \mathrm{g} / \mathrm{ml}$ ACP groups exhibited significantly decreased BSP, OSX and OC expression. OPN expression did not change significantly between the CM and $100 \mu \mathrm{g} / \mathrm{ml}$ ACP groups and the $100 \mu \mathrm{g} / \mathrm{ml}$ ACP group (Fig. 10).

\section{Discussion}


ACP NPs exhibiting favourable bioactivity and bio-conductivity have been reported by previous studies; however, their interaction with immune cells and potential effects on macrophage polarization and immune microenvironments have not been well-explored. The aim of this study was to evaluate the macrophage response to APC NPs. Macrophage polarization and its corresponding cytokine expression, changes in intracellular homeostasis, and protein levels were detected after exposure. The effect of an ACP NP/macrophage-modulated osteo-immune environment on the osteogenic potential of BMSCs was also investigated. Our results demonstrated that ACP NPs polarize macrophages into M1-type cells. Proinflammatory cytokines were upregulated, while anti-inflammatory cytokines did not change obviously. High concentrations of ACP NPs induced the production of ROS, and levels of autophagy increased. ACP $\mathrm{NP} /$ macrophages modulated the osteo-immune environment and weakened the osteogenic ability of BMSCs.

The murine cell line RAW 264.7 was used in the present study because of its close resemblance to human macrophages, which are responsible for innate immunity. Cell morphology is influenced by culture conditions. It has been reported that the morphologies of RAW264.7 cells on biphasic CaP (BCP) ceramic and its degradation products (BPs) showed a large number of protuberances, especially with numerous pseudopods observed in the BP group ${ }^{[6]}$. The topography of the culture surface also influences macrophage morphology. Furthermore, different morphologies of macrophages were correlated with cytokine secretion, which could produce different signalling molecules. In our study, RAW264.7 cells showed good vitality in the ACP NP groups (Figs. 2 and 4). There was no significant apoptosis observed in RAW264.7 cells cultured with more than $100 \mu \mathrm{g} / \mathrm{mL}$ ACP NPs. This result confirms the good biocompatibility of ACP NPs with the cells. However, RAW264.7 cells presented different morphologies between the control and ACP-exposed groups (Fig. 3). ACP NPs regulated the shape of macrophages.

Macrophage function is determined by macrophage polarization and reprogramming. Primary macrophages can be polarized into the pro-inflammatory M1 phenotype or the anti-inflammatory, woundhealing M2 phenotype in responding to different stimuli. Interferon gamma (INFY) and LPS are classical factors that polarize primary macrophages into the M1 phenotype. Interleukin (IL)-4 and IL-13 are cytokines released by immune system that induce macrophage polarization towards the M2 phenotype. The classical M1 macrophage surface markers are CCR7, CD86, CD11C, CD16, CD32, CD64, and CD80. CD36, CD163, CD206 and CD23 are surface markers of M2 macrophages. Macrophage status is characterized by the types of cytokines and growth factors secreted by cells. M1 status is characterized by high expression levels of interleukin TNFa, IL-1 $\beta$ and IL-6, while M2 status is characterized by IL-10, IL4, IL-13, and so on. In our study, the classical markers CD163 and CD206 and the cytokine IL-10 were used to detect M2 polarization, while CCR7, CD86, TNFa and IL-1 $\beta$ were used to detect M1 polarization after ACP NP exposure. The macrophages polarized into the M1 type after exposure. The expression of CD163 and CD206 was significantly downregulated. The high concentration of ACP NPs nonsignificantly decreased IL-10 expression at the transcriptional and protein levels. However, CCR7, CD86 and TNFa and IL-1 $\beta$ expression was significantly upregulated. In previous studies, the different physicochemical properties of NPs, such as particle size and charge, may have had different effects on macrophage 
polarization and function. For example, copper-doped mesoporous silica nanospheres (Cu-MSNs) polarize macrophages into the M1 phenotype. The surface markers CCR7 and CD11c were upregulated significantly after incubation in Cu-MSN-enriched medium. Correspondingly, IL-6, TNFa, IL-1 $\beta$ and IFN, which are pro-inflammatory mediators, were consistently upregulated in this group. Evidenced by the highly increased activity levels of IL-1 $\beta$ and TNF-a, SiO2 NPs stimulated U-937 cell polarization towards the M1 phenotype. At the same particle size, Au NPs seemed to have a greater effect on M1 macrophage polarization than Ag NPs. However, other researchers have reported that Ag NPs (15 and $40 \mathrm{~nm}$ ) exhibit a higher ability to stimulate M1 activation than Au NPs (20 and $40 \mathrm{~nm}$ ), as evidenced by the detection of TNF- $a$ and IL-6 expression. However, some types of nanoparticles did not change the phenotype of the cells. For example, titanium oxide $\left(\mathrm{TiO}_{2}\right) \mathrm{NPs}(70 \mathrm{~nm})$ and the more inert zirconium oxide $\left(\mathrm{ZrO}_{2}\right) \mathrm{NPs}(5-$ $30 \mathrm{~nm}$ ) did not induce phenotype changes in primary macrophages. Thus, the different physical and chemical properties of NPs have different effects on macrophage polarization.

Oxidative stress is one of the indexes that reflect the changes of intracellular homeostasis. ROS generation was assessed by FCM. ROS production was upregulated at $200 \mu \mathrm{g} / \mathrm{mL}$ ACP NPs. Autophagy also plays an important role in maintaining intracellular homeostasis, and it actively participates in the immune response. Calcium ions regulate autophagy both positively and negatively. Intracellular calcium is stored mainly in the ER lumen and released upon stimulation'. To maintain the bioenergetic production of ATP, small amounts of calcium should be released from the ER spontaneously. Autophagy will be triggered by reductions in intracellular calcium levels. However, autophagy will also be triggered by increased calcium release from the ER or extracellular space. In a $\mathrm{TMT}^{\mathrm{TM}}$ quantitative protein analysis, we found that the upregulated proteins were enriched in response to calcium ions and metal ions. ACP NPS promote autophagy by downregulating p62 and change LC3 expression. The change in the autophagy level may be caused by calcium ion release from ACP NPs. Molecular function was also related to calcium ion binding. Furthermore, particle size and surface morphology influenced the autophagy level of cells. Chen et al. investigated the macrophage responses to nano-porous anodic alumina with differently sized pores. The nanopore structure and pore size were found to regulate the expression and activation of autophagy pathway components (LC3A/B, Beclin-1, Atg3, Atg7, and p62) and modulate intracellular homeostasis.

Since ACP particles change the morphology and function of immune cells, the particle-mediated effects of the microenvironment on osteogenesis are not clear. Cell morphology, proliferation, ALP activity, mineralization, and osteogenic gene expression were monitored to investigate the behaviour of BMSCs. ACP NPs promoted BMSC proliferation (Fig. 2). Cytoskeletal staining showed that ACP NPs regulated the shape of BMSCs (figs). To further explain the effects of the ACP NP/macrophage-modulated environment on osteogenic differentiation of BMSCs, we used ALP staining and mineralization staining and examined osteogenic gene expression in CM. Macrophage-related microenvironments that influence osteogenesis have been reported in some studies. Chen et al. reported that nano-porous microstructures mediate osteogenesis by modulating the osteo-immune response of macrophages ${ }^{[34]}$. An immune microenvironment induced by Cu-MSNs led to robust osteogenic differentiation of BMSCs via the 
activation of the oncostatin M (OSM) pathway ${ }^{[24]}$. The surface chemistry and nano-topography scale modulated the macrophage-related osteo-immune environment by changing the expression levels of inflammatory cytokines, osteoclastic activities, and osteogenic, angiogenic, and fibrogenic factors.

The mechanism underlying the macrophage-related microenvironment influence on the osteogenic differentiation of MSCs is partly dependent on a switch of macrophage phenotype. The polarization of macrophages to $\mathrm{M} 2$ rather than the inflammatory M1 phenotype promotes osteogenesis. M2 macrophages not only promoted BMSC osteogenesis but also stimulated the biomineralization of adipose tissue MSCs. Patterned titanium surfaces and macrophages prefer to polarize to $M 2$, while macrophages on traditional titanium coatings prefer $\mathrm{M} 1$ polarization. RAW cells/patterned coating-CM promoted the osteogenic property of BMSCs. In odontogenic differentiation, M1 macrophage CM did not affect the ALP activity of human dental pulp cells (HDPCs). In our study, ACP NPs promoted macrophage polarization to the M1 phenotype, and pro-inflammatory mediator levels were increased in culture medium. The ACP NP/macrophage-modulated environment decreased ALP activity, which is an early marker for osteoblastic differentiation, and inhibited BMSC mineralization, which is the last stage of osteoblastic differentiation. A previous study also reported that BCP ceramic and its BPs upregulate IL-1, IL- 6 and MCP-1 expression, as well as VEGF, PDGF and EGF. CM promoted the migration of MSCs and the gene expression of osteogenic markers (ALP, COL-I, OSX, BSP and OPN). CMs promoted the osteoblastic differentiation of MSCs as determined by ALP activity and mineralization staining ${ }^{[6]}$. This result is contrary to our findings. The reason is that physical and chemical properties of the two materials such as particle size and crystalline form are different. It has been reported that sub-micrometre strontiumcontaining bioactive microspheres promote in vivo early angiogenesis through modulating macrophage phenotypes. RAW cells trended towards the M2 phenotype by exposure to extracts of strontiumcontaining bioactive microspheres. These extracts also modulate macrophage responses for improved bone regeneration. However, using extracts to test macrophage responses is different from using particles. In our study, we used NPs to directly stimulate RAW cells, and these results were more objective. From our findings, ACP NPs may cause aseptic inflammation.

\section{Conclusion}

ACP NPs change macrophage morphology and polarize macrophages into the M1 type. Pro-inflammatory cytokines are upregulated, while the anti-inflammatory cytokines do not change obviously. ACP NPS increase levels of autophagy, and high concentrations of ACP NPs induce the production of ROS. ACP $\mathrm{NP} /$ macrophage-modulated environments weaken the osteogenic ability of BMSCs.

\section{Declarations}

\section{Ethics approval and consent to participate}

Not applicable. 


\section{Consent for publication}

Not applicable.

\section{Availability of data and materials}

The datasets used and/or analysed in the current study are available from the corresponding author on reasonable request.

\section{Competing interests}

The authors declare that they have no competing interests.

\section{Funding}

This work was supported financially by the National Natural Science Fund (81600904 and 81771102), High technology research and development program of China (863 program, 2015AA033502) and the incubation programme of Guangzhou Medical University (Nos. B185004177).

\section{Authors' contributions}

LJC, HCL and LQS designed the research. LJC was responsible for characterize ACP NPs, detect macrophage polarization and cytokine expression. ROS and autophagy expression were evaluated by LJC and PYQ. TMT ${ }^{\mathrm{TM}}$ quantitative protein analysis and BMSC osteogenic differentiation was detected by LJC and PYQ. LJC generated the figures and drafted the manuscript, which was critically revised by HCL and LQS. All authors have read, corrected and approved the manuscript.

\section{References}

1. Choi H, Park NJ, Jamiyandorj O, Hong MH, Oh S, Park YB, Kim S. Improvement of osteogenic potential of biphasic calcium phosphate bone substitute coated with synthetic cell binding peptide sequences. J Periodontal Implant Sci. 2012, 42(5):166-172.

2. Velard F, Braux J, Amedee J, Laquerriere P. Inflammatory cell response to calcium phosphate biomaterial particles: an overview. Acta Biomater. 2013, 9(2):4956-4963.

3. Accorsi-Mendonça T, Conz MB, Barros TC, de Sena LA, Soares Gde A, Granjeiro JM. Physicochemical characterization of two deproteinized bovine xenografts. Braz Oral Res. 2008 , 22(1):5-10.

4. Daculsi G, Legeros JP. Three-dimensional defects in hydroxyapatite of biological interest. J Biomed Mater Res. 1996,31(4):495-501.

5. Prudhommeaux F, Schiltz C, Lioté F, Hina A, Champy R, Bucki B, Ortiz-Bravo E, Meunier A, Rey C, Bardin T. Variation in the inflammatory properties of basic calcium phosphate crystals according to crystal type. Arthritis Rheum. 1996, 39(8):1319-26. 
6. Wang J, Liu D, Guo B, Yang X, Chen X, Zhu X, Fan Y, Zhang X. Role of biphasic calcium phosphate ceramic-mediated secretion of signaling molecules by macrophages in migration and osteoblastic differentiation of MSCs. Acta Biomater. 2017,$15 ; 51: 447-460$.

7. Jones JA, Chang DT, Meyerson H, Colton E, Kwon IK, Matsuda T, Anderson JM. Proteomic analysis and quantification of cytokines and chemokines from biomaterial surface-adherent macrophages and foreign body giant cells. J Biomed Mater Res A. 2007,83(3):585-596.

8. Oh J, Riek AE, Weng S, Petty M, Kim D, Colonna M, Cella M, Bernal-Mizrachi C.

9. Endoplasmic reticulum stress controls $\mathrm{M} 2$ macrophage differentiation and foam cell formation. $\mathrm{J}$ Biol Chem. 2012, 287(15):11629-11641.

10. Rao AJ, Gibon E, Ma T, Yao Z, Smith RL, Goodman SB. Revision joint replacement, wear particles, and macrophage polarization. Acta Biomater. 2012, 8(7):2815-2823.

11. Lotsari A, Rajasekharan AK, Halvarsson M, Andersson M. Transformation of amorphous calcium phosphate to bone-like apatite. Nat Commun, 2018 , 9(1):4170.

12. Iafisco M, Degli Esposti L, Ramírez-Rodríguez GB, Carella F, Gómez-Morales J, lonescu AC, Brambilla E, Tampieri A, Delgado-López JM. Fluoride-doped amorphous calcium phosphate nanoparticles as a promising biomimetic material for dental remineralization. Sci Rep. 2018, 8(1):17016.

13. Cai X, Han B, Liu Y, Tian F, Liang F, Wang X. Chlorhexidine-Loaded Amorphous Calcium Phosphate Nanoparticles for Inhibiting Degradation and Inducing Mineralization of Type I Collagen. ACS Appl Mater Interfaces. 2017, 9(15):12949-12958.

14. Feng G, Qin C, Yi X, Xia J, Chen J, Chen X, Chen T, Jiang X. Effect of novel bioresorbable scaffold composed of poly-L-lactic acid and amorphous calcium phosphate nanoparticles on inflammation and calcification of surrounding tissues after implantation. J Mater Sci Mater Med. 2018, 29(8):112.

15. Brancato SK, Albina JE. Wound macrophages as key regulators of repair: origin, phenotype, and function. Am J Pathol. 2011, 178(1):19-25.

16. Chen S, Jones JA, Xu Y, Low HY, Anderson JM, Leong KW. Characterization of topographical effects on macrophage behavior in a foreign body response model. Biomaterials. 2010, 31(13):3479-3491.

17. Lee HS, Stachelek SJ, Tomczyk N, Finley MJ, Composto RJ, Eckmann DM. Correlating macrophage morphology and cytokine production resulting from biomaterial contact. J Biomed Mater Res A. 2013, 101(1):203-212.

18. Murray PJ, Allen JE, Biswas SK, Fisher EA, Gilroy DW, Goerdt S, Gordon S, Hamilton JA, Ivashkiv LB, Lawrence T, Locati M, Mantovani A, Martinez FO, Mege JL, Mosser DM, Natoli G, Saeij JP, Schultze JL, Shirey KA, Sica A, Suttles J, Udalova I, van Ginderachter JA, Vogel SN, Wynn TA. Macrophage activation and polarization: nomenclature and experimental guidelines. Immunity. 2014,41(1):14-20.

19. Bain CC, Schridde A. Origin, Differentiation, and Function of Intestinal Macrophages. Front Immunol. 2018, 27;9:2733.

20. Murray PJ. Macrophage Polarization. Annu Rev Physiol. 2017, 79:541-566. 
21. Hotchkiss KM, Reddy GB, Hyzy SL, Schwartz Z, Boyan BD, Olivares-Navarrete R. Titanium surface characteristics, including topography and wettability, alter macrophage activation. Acta Biomater. 2016, 31:425-434.

22. Mantovani A, Biswas SK, Galdiero MR, Sica A, Locati M. Macrophage plasticity and polarization in tissue repair and remodelling. J Pathol. 2013, 229(2):176-185.

23. Pajarinen J, Kouri VP, Jämsen E, Li TF, Mandelin J, Konttinen YT. The response of macrophages to titanium particles is determined by macrophage polarization. Acta Biomater. 2013, 9(11):9229-9240.

24. Miao X, Leng X, Zhang Q.The Current State of Nanoparticle-Induced Macrophage Polarization and Reprogramming Research. Int J Mol Sci. 2017 Feb 6;18(2). pii: E336.

25. Shi M, Chen Z, Farnaghi S, Friis T, Mao X, Xiao Y, Wu C. Copper-doped mesoporous silica nanospheres, a promising immunomodulatory agent for inducing osteogenesis. Acta Biomater. 2016, 30:334-344.

26. Lucarelli M, Gatti AM, Savarino G, Quattroni P, Martinelli L, Monari E, Boraschi D. Innate defence functions of macrophages can be biased by nano-sized ceramic and metallic particles. Eur Cytokine Netw. 2004, 15(4):339-346.

27. Yen HJ, Hsu SH, Tsai CL. Cytotoxicity and immunological response of gold and silver nanoparticles of different sizes. Small. 2009, 5(13):1553-1561.

28. Nishanth RP, Jyotsna RG, Schlager JJ, Hussain SM, Reddanna P. Inflammatory responses of RAW 264.7 macrophages upon exposure to nanoparticles: role of ROS-NFKB signaling pathway. Nanotoxicology. 2011, 5(4):502-516.

29. Manke A, Wang L, Rojanasakul Y. Mechanisms of nanoparticle-induced oxidative stress and toxicity. Biomed Res Int. 2013;2013:942916.

30. Gordon PB, Holen I, Fosse M, Røtnes JS, Seglen PO. Dependence of hepatocytic autophagy on intracellularly sequestered calcium. J Biol Chem. 1993, 268(35):26107-26112.

31. Decuypere JP, Bultynck G, Parys JB. A dual role for $\mathrm{Ca}(2+)$ in autophagy regulation. Cell Calcium. 2011, 50(3):242-250.

32. Cárdenas C, Miller RA, Smith I, Bui T, Molgó J, Müller M, Vais H, Cheung KH, Yang J, Parker I, Thompson CB, Birnbaum MJ, Hallows KR, Foskett JK. Essential regulation of cell bioenergetics by constitutive InsP3 receptor Ca2+ transfer to mitochondria. Cell. 2010,142(2):270-283.

33. Williams A, Sarkar S, Cuddon P, Ttofi EK, Saiki S, Siddiqi FH, Jahreiss L, Fleming A, Pask D, Goldsmith P, O'Kane CJ, Floto RA, Rubinsztein DC. Novel targets for Huntington's disease in an mTORindependent autophagy pathway. Nat Chem Biol. 2008, 4(5):295-305.

34. Høyer-Hansen M1, Bastholm L, Szyniarowski P, Campanella M, Szabadkai G, Farkas T, Bianchi K, Fehrenbacher N, Elling F, Rizzuto R, Mathiasen IS, Jäättelä M. Control of macroautophagy by calcium, calmodulin-dependent kinase kinase-beta, and Bcl-2. Mol Cell. 2007, 25(2):193-205.

35. Chen Z, Ni S, Han S, Crawford R, Lu S, Wei F, Chang J, Wu C, Xiao Y. Nanoporous microstructures mediate osteogenesis by modulating the osteo-immune response of macrophages. Nanoscale. 2017, 9(2):706-718. 
36. Ma QL, Zhao LZ, Liu RR, Jin BQ, Song W, Wang Y, Zhang YS, Chen LH, Zhang YM. Improved implant osseointegration of a nanostructured titanium surface viamediation of macrophage polarization. Biomaterials. 2014, 35(37): 9853-9867.

37. Chen Z, Bachhuka A, Han S, Wei F, Lu S, Visalakshan RM, Vasilev K, Xiao Y. Tuning Chemistry and Topography of Nanoengineered Surfaces to Manipulatelmmune Response for Bone Regeneration Applications. ACS Nano. 2017, 11(5):4494-4506.

38. Yang CL, Sun YH, Yu WH, Yin XZ, Weng J, Feng B. Modulation of macrophage phenotype through controlled release of interleukin-4 from gelatine coatings on titanium surfaces. Eur Cell Mater. 2018, 36:15-29.

39. Jamalpoor Z, Asgari A, Lashkari MH, Mirshafiey A, Mohsenzadegan M. Modulation of Macrophage Polarization for Bone Tissue Engineering Applications. Iran J Allergy Asthma Immunol. 2018, 17(5):398-408.

40. Zhang Y, Böse T, Unger RE, Jansen JA, Kirkpatrick CJ, van den Beucken JJJP. Macrophage type modulates osteogenic differentiation of adipose tissue MSCs. Cell Tissue Res. 2017, 369(2):273-286.

41. Zhang Z, Xie Y, Pan H, Huang L, Zheng X. Influence of patterned titanium coatings on polarization of macrophage and osteogenic differentiation of bone marrow stem cells. J Biomater Appl. 2018, 32(7):977-986.

42. Park HC, Quan H, Zhu T, Kim Y, Kim B, Yang HC. The Effects of M1 and M2 Macrophages on Odontogenic Differentiation of Human Dental Pulp Cells. J Endod. 2017, 43(4):596-601.

43. Chudinova EA, Surmeneva MA, Timin AS, Karpov TE, Wittmar A, Ulbricht M, Ivanova A, Loza K, Prymak O, Koptyug A, Epple M, Surmenev RA. Adhesion, proliferation, and osteogenic differentiation of human mesenchymal stem cells on additively manufactured Ti6Al4V alloy scaffolds modified with calcium phosphate nanoparticles. Colloids Surf B Biointerfaces. 2018, 176:130-139.

44. Zhao F, Lei B, Li X, Mo Y, Wang R, Chen D, Chen X. Promoting in vivo early angiogenesis with submicrometer strontium-contained bioactive microspheres through modulating macrophage phenotypes. Biomaterials. 2018, 178:36-47.

45. Zhang W, Zhao F, Huang D, Fu X, Li X, Chen X. Strontium-Substituted Submicrometer Bioactive Glasses Modulate Macrophage Responses for Improved Bone Regeneration. ACS Appl Mater Interfaces. 2016, 8(45):30747-30758.

\section{Figures}


A
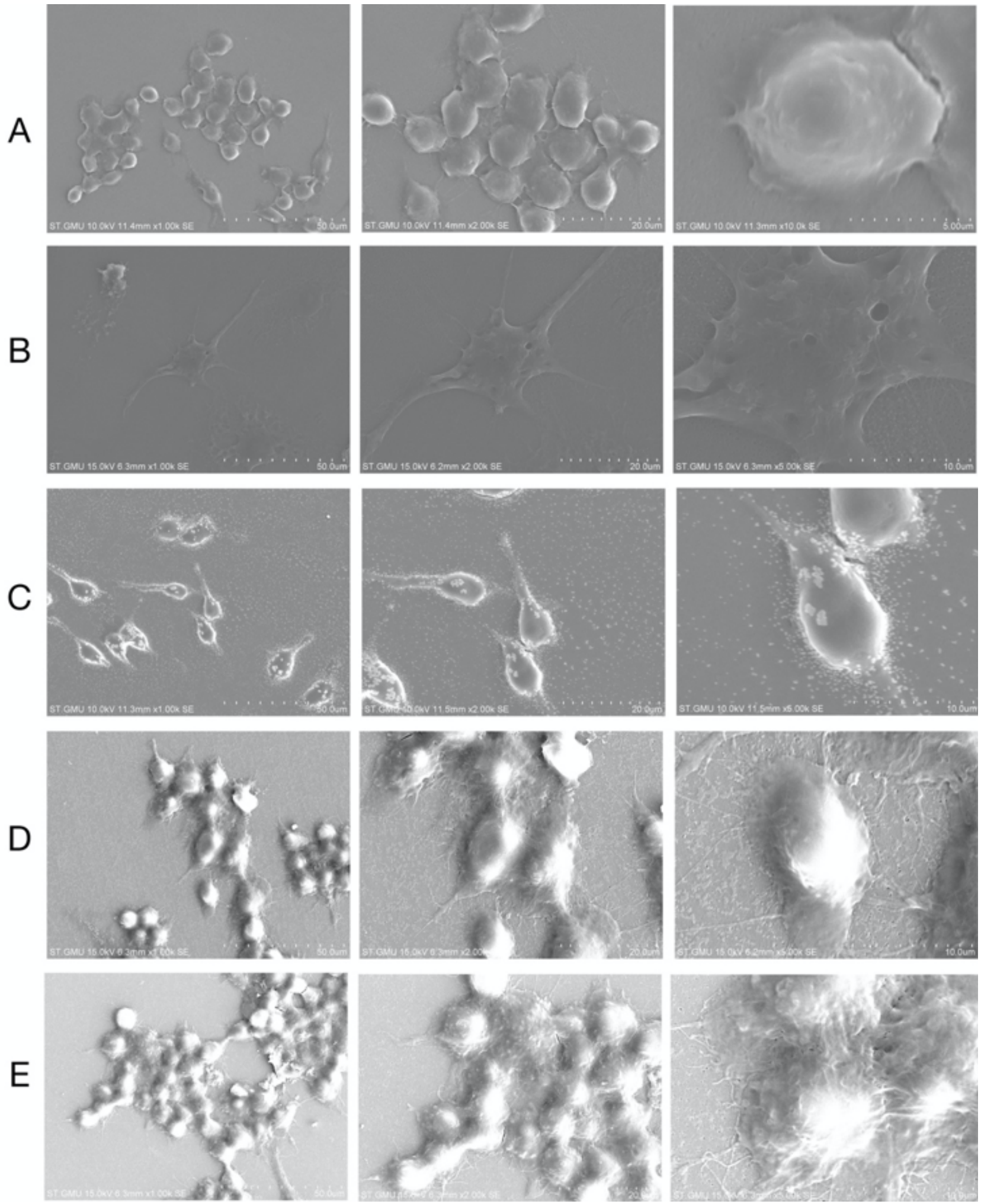

\section{Figure 1}

SEM observation of RAW 264.7 cells A. Negative control group: the cells were round, and the edges of the cells were very smooth. B. LPS group: the cells spread obvious pseudopods. C. In the $50 \mu \mathrm{g} / \mathrm{mL}$ ACP group, the cell morphology was still round. D and E show the 100 and $150 \mu \mathrm{g} / \mathrm{mL}$ ACP groups, where the cells extended tiny pseudopods. 

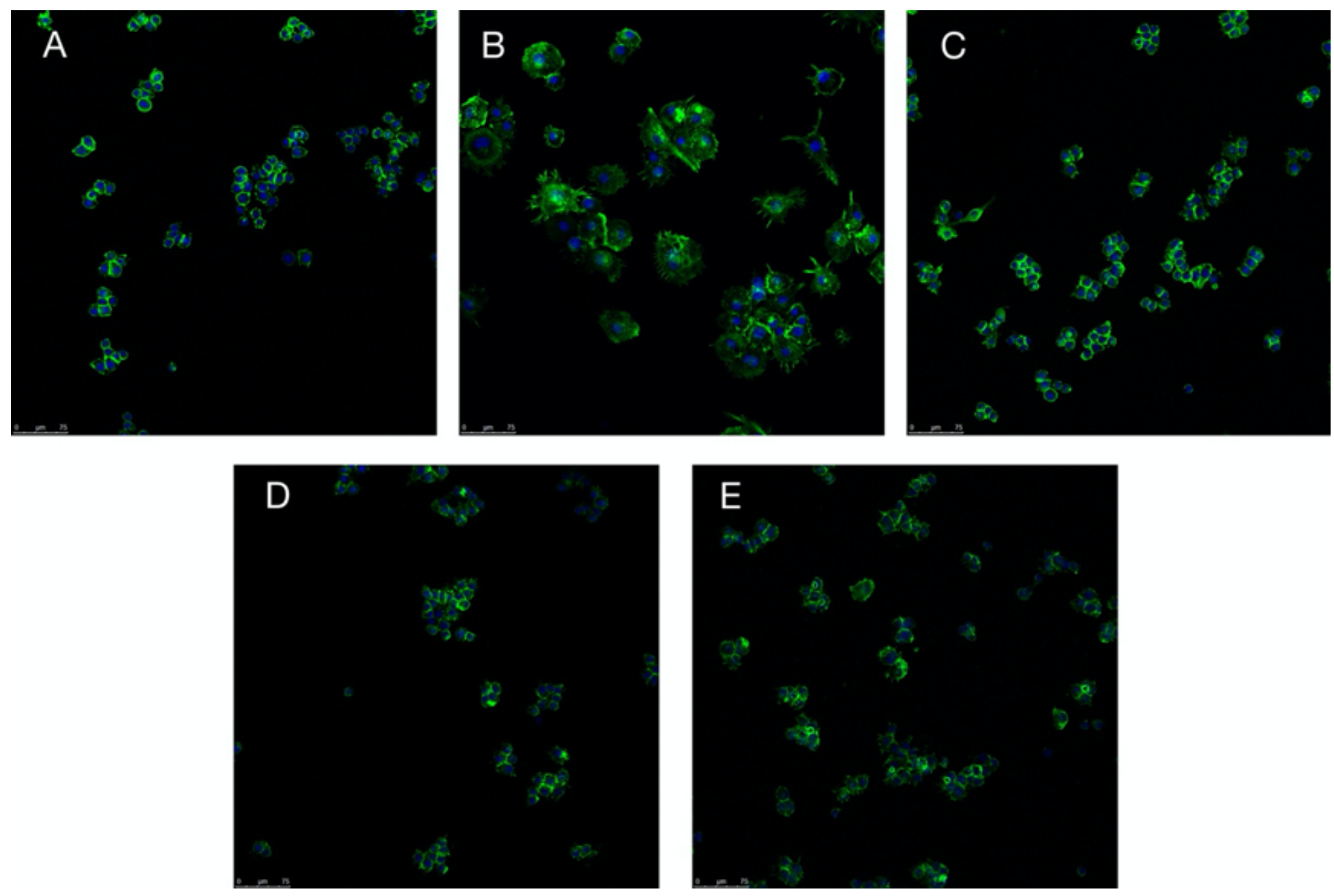

\section{Figure 2}

Cytoskeletal staining of RAW264.7 cells A. Negative control group: the cells were round. B. LPS group: the cells swelled and spread obvious pseudopods. C. In the $50 \mu \mathrm{g} / \mathrm{mL}$ ACP group, the cell morphology was still round. D and E show the 100 and $150 \mu \mathrm{g} / \mathrm{mL}$ ACP groups, where the cells extended tiny pseudopods. Images were taken at $40 x$ magnification (scale bar $=75 \mu \mathrm{m}$ ). 
24h

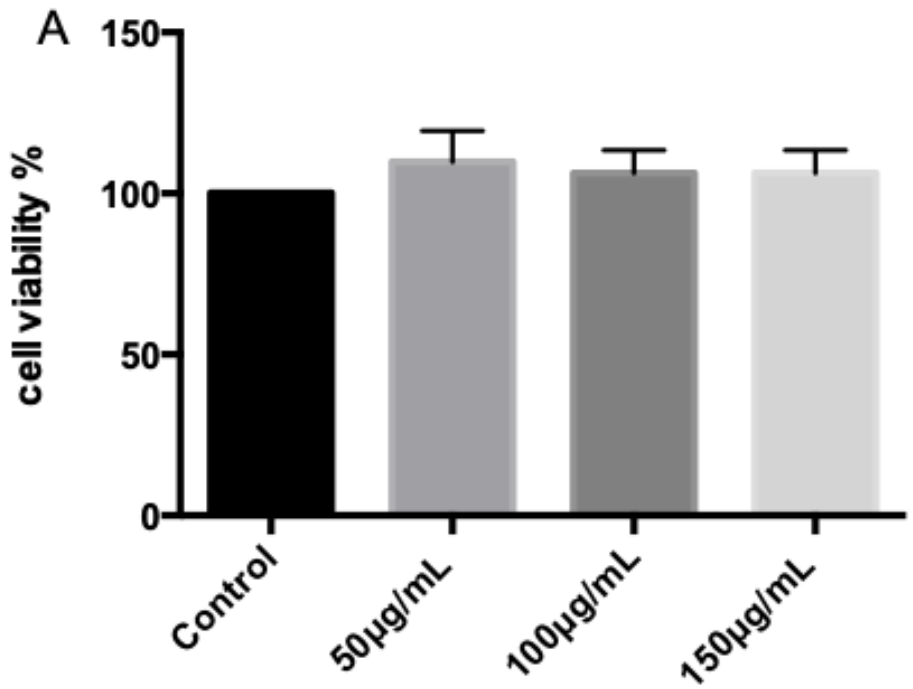

RAW 264.7

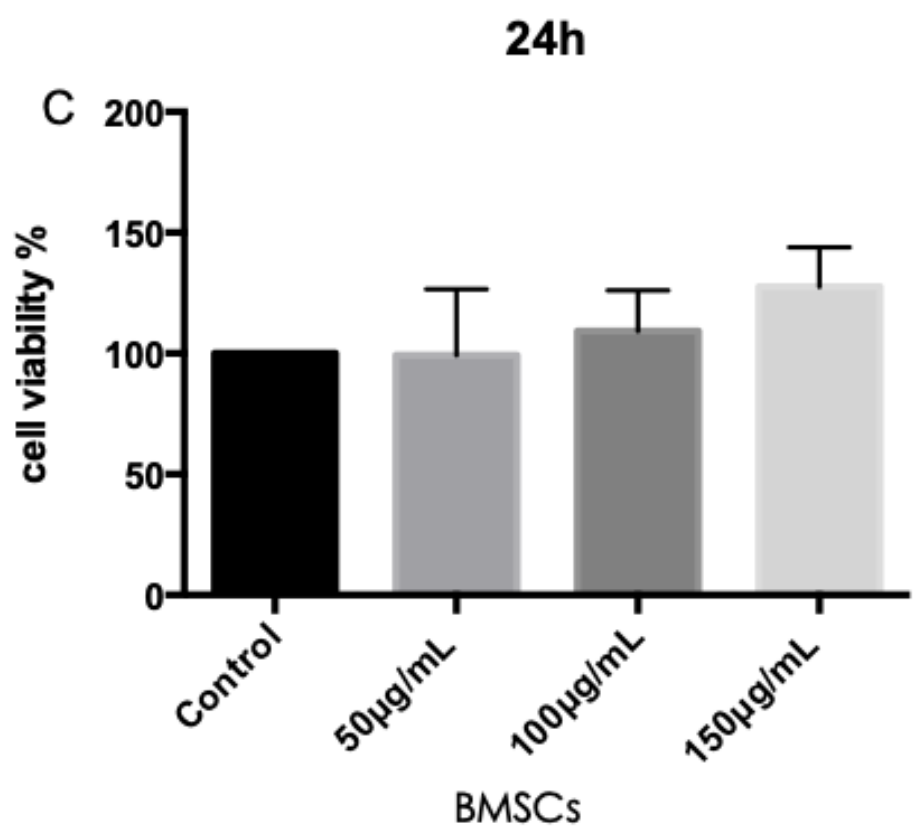

$48 h$

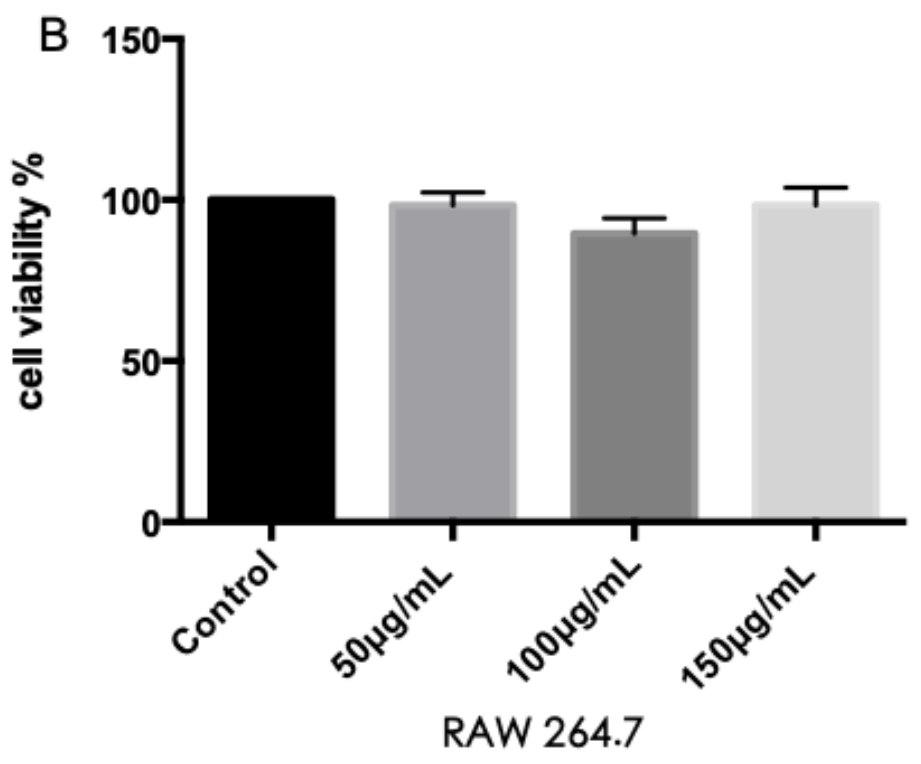

$48 h$

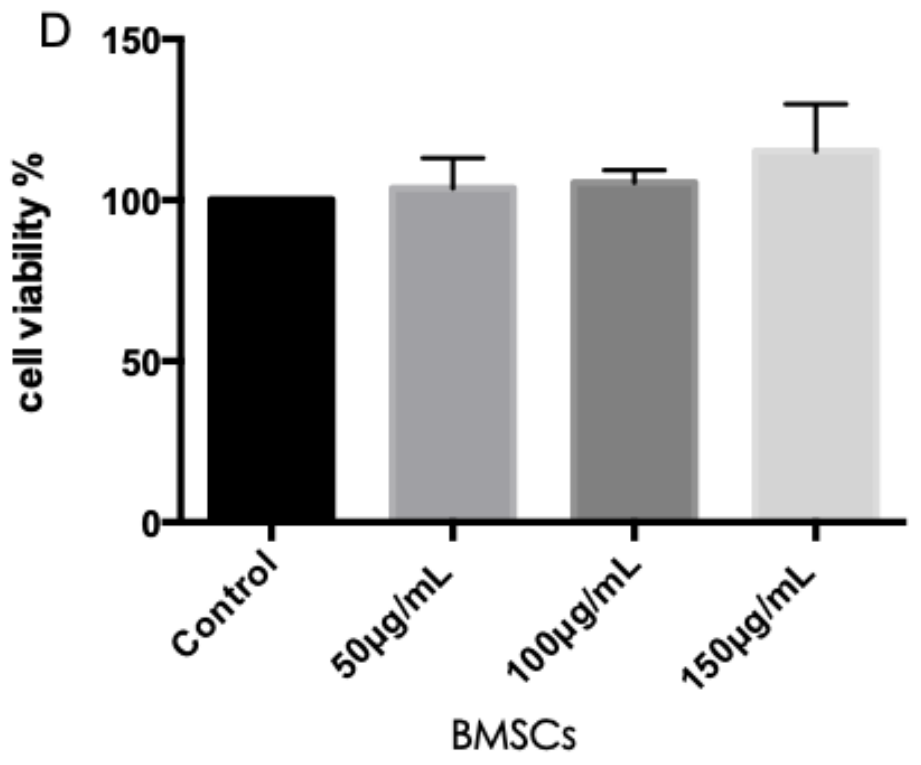

Figure 3

Cell proliferation of RAW 264.7 cells and BMSCs A and B show RAW 264.7 cell proliferation rates. The rates were greater than $95 \%$ or greater than $100 \%$ after nanoparticle exposure. $C$ and D show BMSC proliferation rates. The rates were close to or greater than $100 \%$ after nanoparticle exposure. 

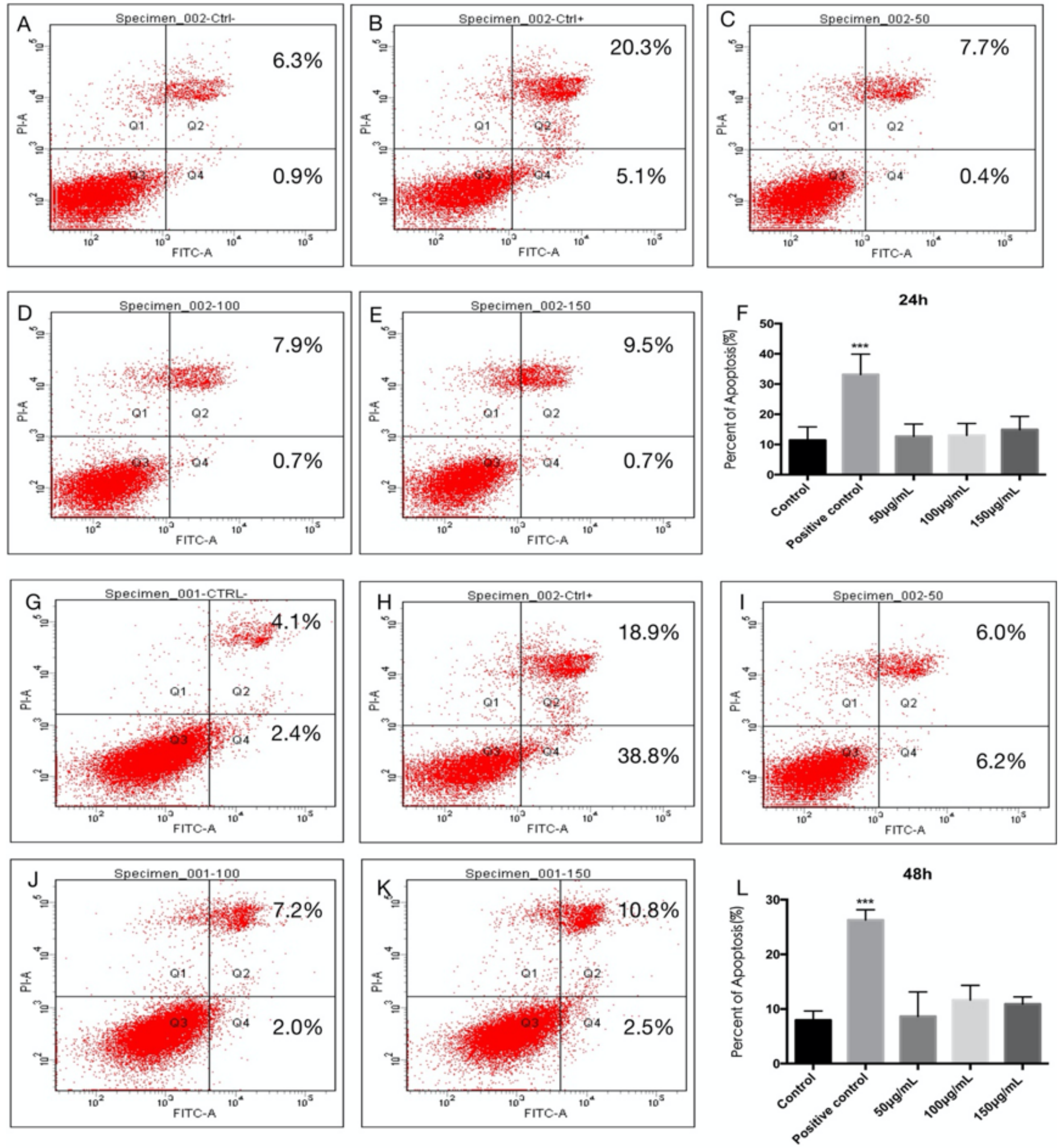

\section{Figure 4}

No obvious signs of apoptosis were observed in RAW264.7 cells cultured with ACP after $24 \mathrm{~h}$ and $48 \mathrm{~h}$. Graphical representations of normally cultured RAW264.7 cells (A) and cells cultured with a $0.64 \%$ phenol solution (B and $\mathrm{H}$ ) or 50 (C and I), 100 (D and J), or $150 \mu \mathrm{g} / \mathrm{mL}$ ACP (E and K) are shown. Approximately $9 \%$ of RAW264.7 cells underwent apoptosis in the control group, and approximately $10 \%$ of the cells 
underwent apoptosis in the 50,100, and $150 \mu \mathrm{g} / \mathrm{mL}$ ACP groups. No significant difference was found among these groups $(F$ and $L)$. All values are presented as the means $\pm S D$ of triplicate experiments.
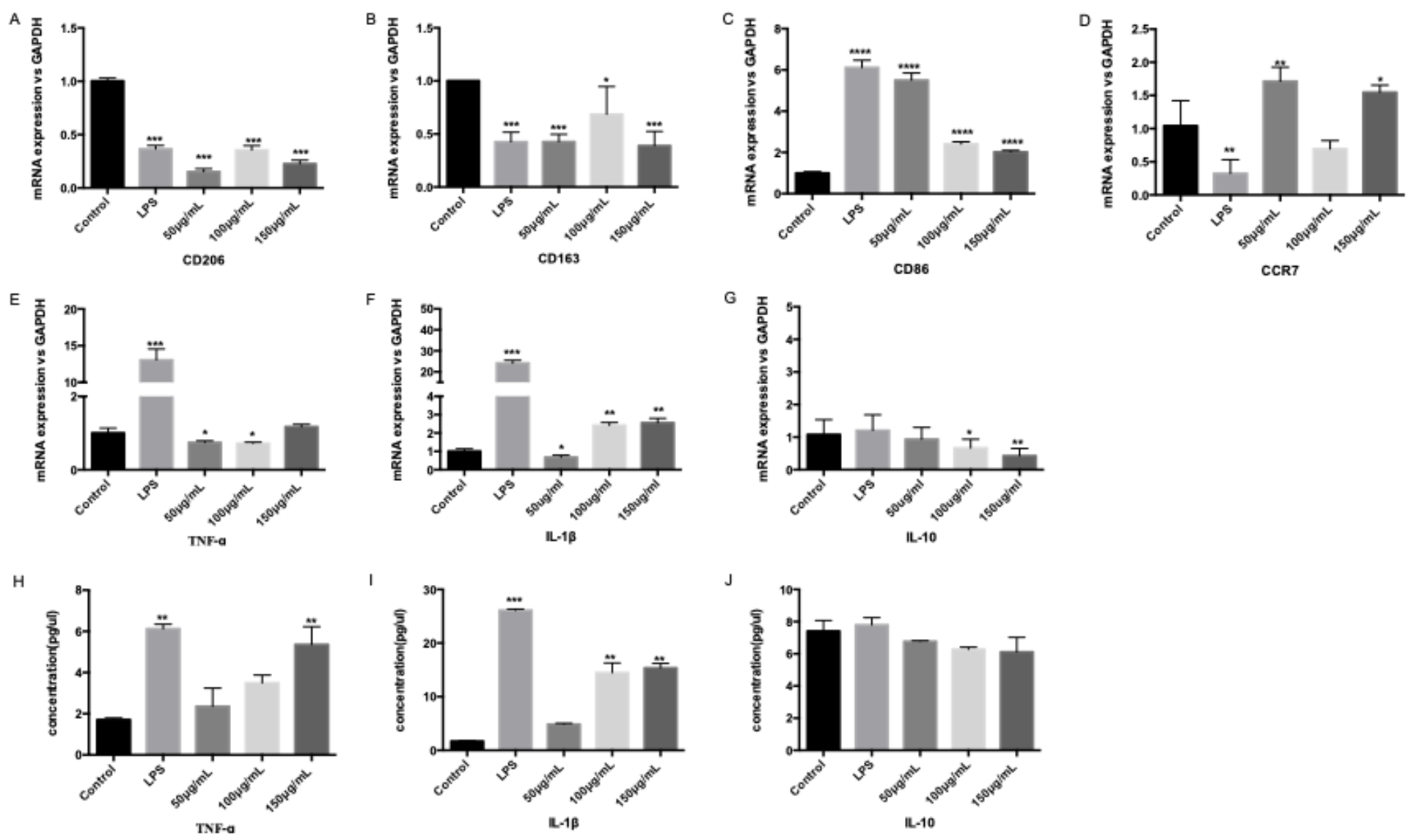

\section{Figure 5}

Polarization of macrophages and expression of M1 and M2 cytokines CD206 and CD163 were significantly downregulated ( $A$ and $B$ ). CD86 was upregulated significantly, and CCR7 was upregulated in the $50 \mu \mathrm{g} / \mathrm{mL}$ and $150 \mu \mathrm{g} / \mathrm{mL}$ groups (C and D). Macrophages polarized to the M1 phenotype. The expression of TNF-a in the $50 \mu \mathrm{g} / \mathrm{mL}$ and $100 \mu \mathrm{g} / \mathrm{mL}$ groups was downregulated, and there was no significant change in the $150 \mu \mathrm{g} / \mathrm{mL}$ group (E). IL-1 $\beta$ was significantly upregulated in all ACP groups (F). No significant IL-10 expression change was observed (G). ELISA results showed that TNF-a was upregulated in only the $150 \mu \mathrm{g} / \mathrm{mL}$ ACP group $(\mathrm{H})$, and IL-1 $\beta$ was upregulated in the $100 \mu \mathrm{g} / \mathrm{mL}$ and 150 $\mu \mathrm{g} / \mathrm{mL}$ ACP groups (I). IL-10 expression was downregulated slightly with no significance. 


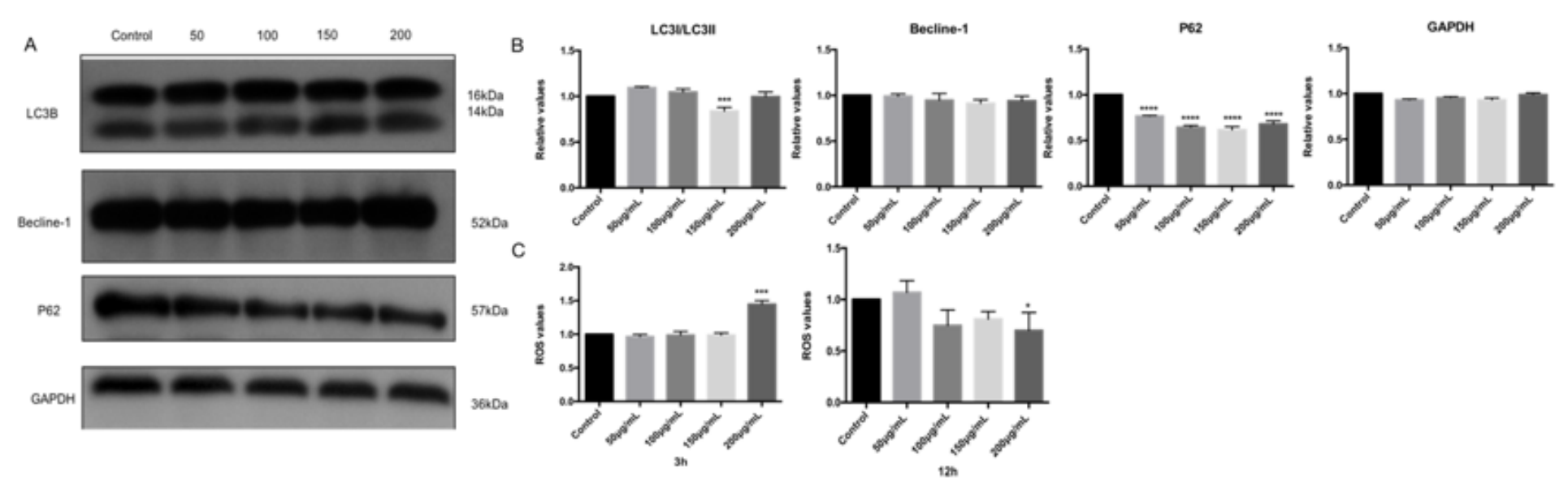

Figure 6

autophagy and ROS production The expression of p62 was downregulated ( $a$ and $b$ ) with increasing concentration. The LC3I to LC3II ratio decreased at $150 \mathrm{ug} / \mathrm{ml}$ significantly. ACP particles increased ROS production at $200 \mu \mathrm{g} / \mathrm{ml}$ in $3 \mathrm{~h}$ (c).
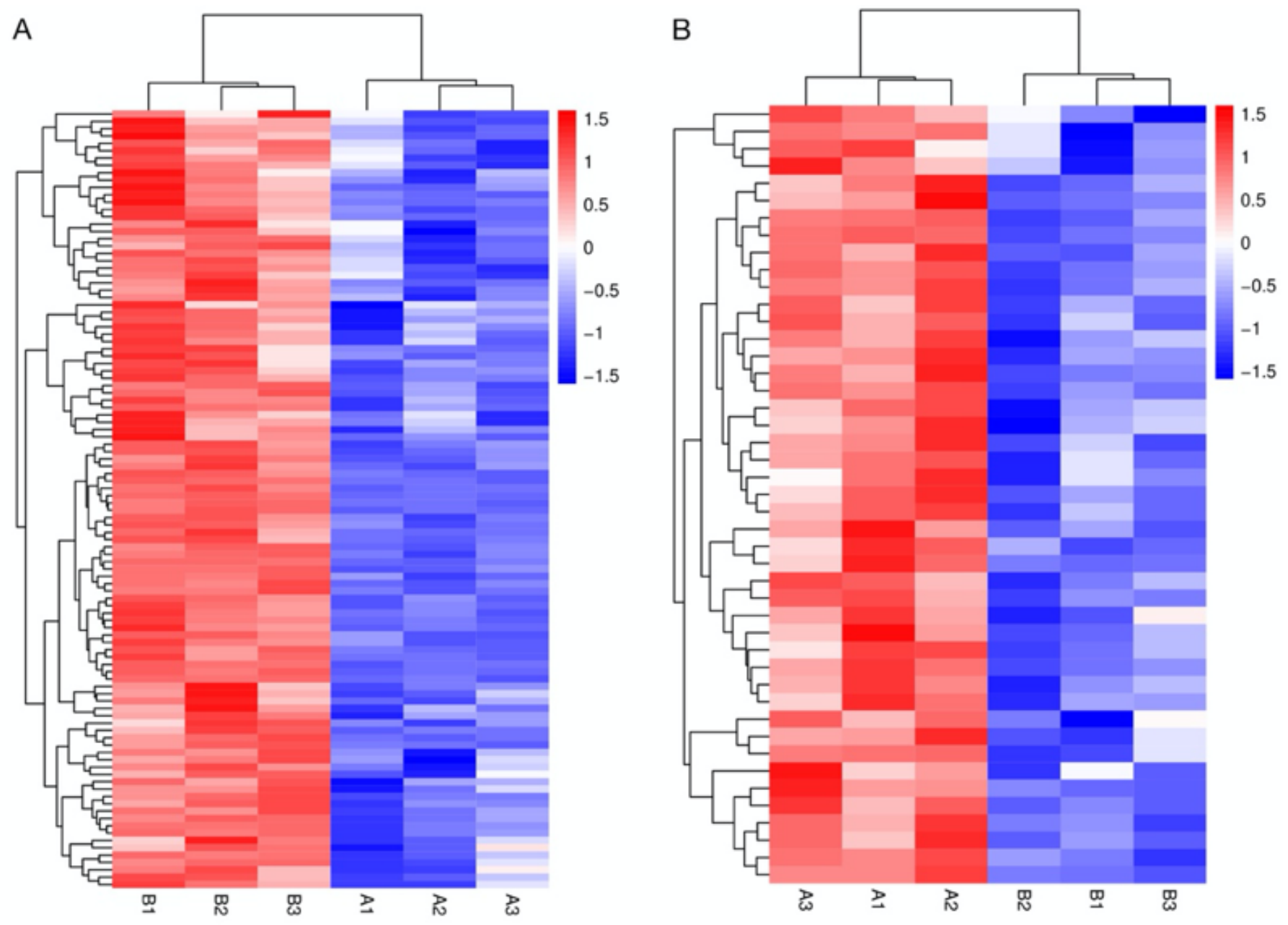

Figure 7

Differential expression heat map of upregulated proteins $(A)$ and downregulated proteins (B) 

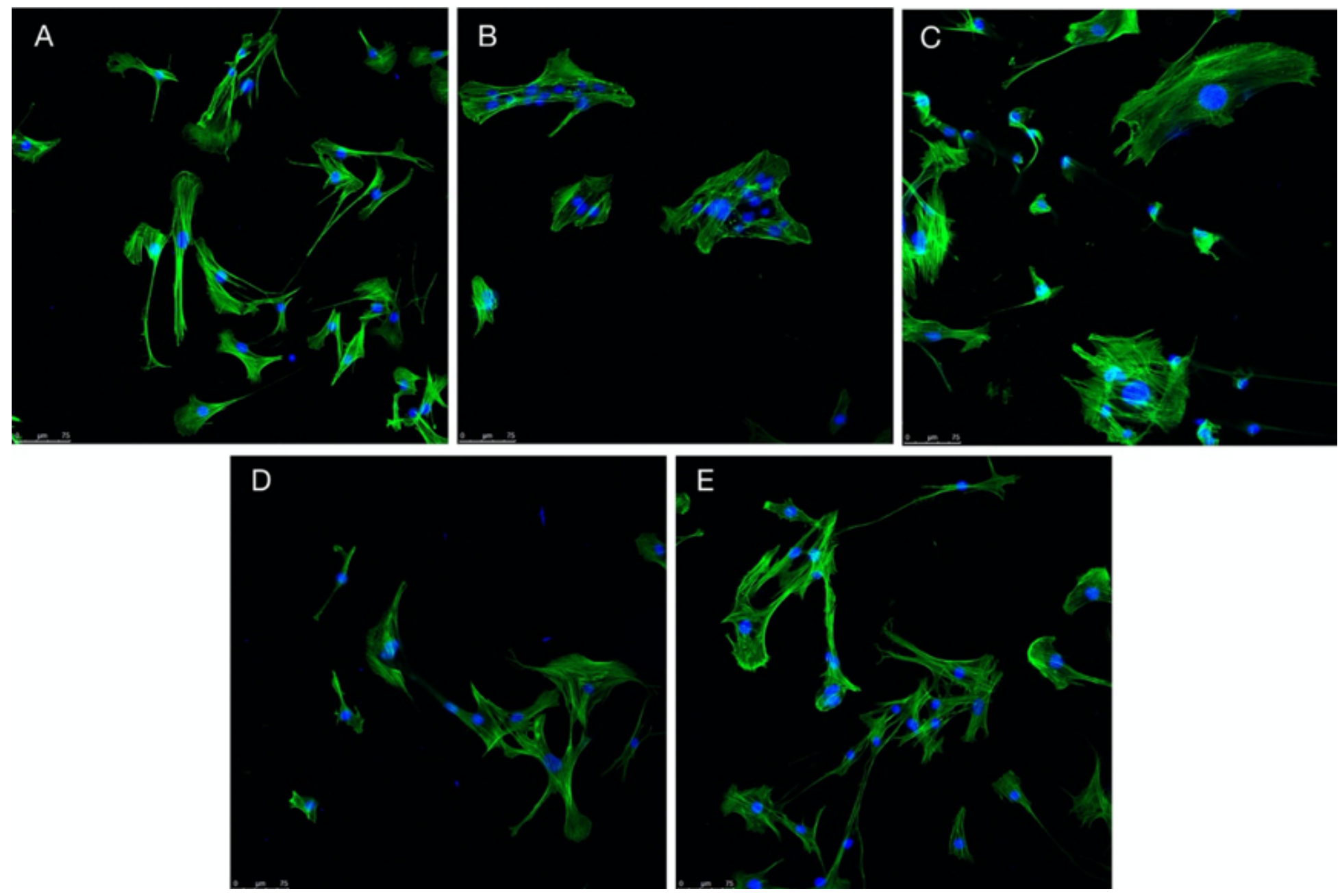

\section{Figure 8}

Cytoskeletal staining of BMSCs A. PM group. B. OM group. C. $50 \mu \mathrm{g} / \mathrm{mL}$ ACP group. D. $100 \mu \mathrm{g} / \mathrm{mL}$ ACP group. E. $150 \mu \mathrm{g} / \mathrm{mL}$ ACP group. (Scale bar $=75 \mu \mathrm{m}$ ).

展

\section{Figure 9}

ALP staining results for days 1, 3 and 7. Alizarin Red staining results for days 7 and 14. The CM group decreased ALP activity at $1 \mathrm{~d}$, and compared to the $100 \mu \mathrm{g} / \mathrm{ml}$ ACP group, the CM and $100 \mu \mathrm{g} / \mathrm{ml}$ ACP groups showed decreased ALP activity at $1 \mathrm{~d}$. The CM group and the CM and $100 \mu \mathrm{g} / \mathrm{ml}$ ACP groups weakened the formation of mineralized nodules. 

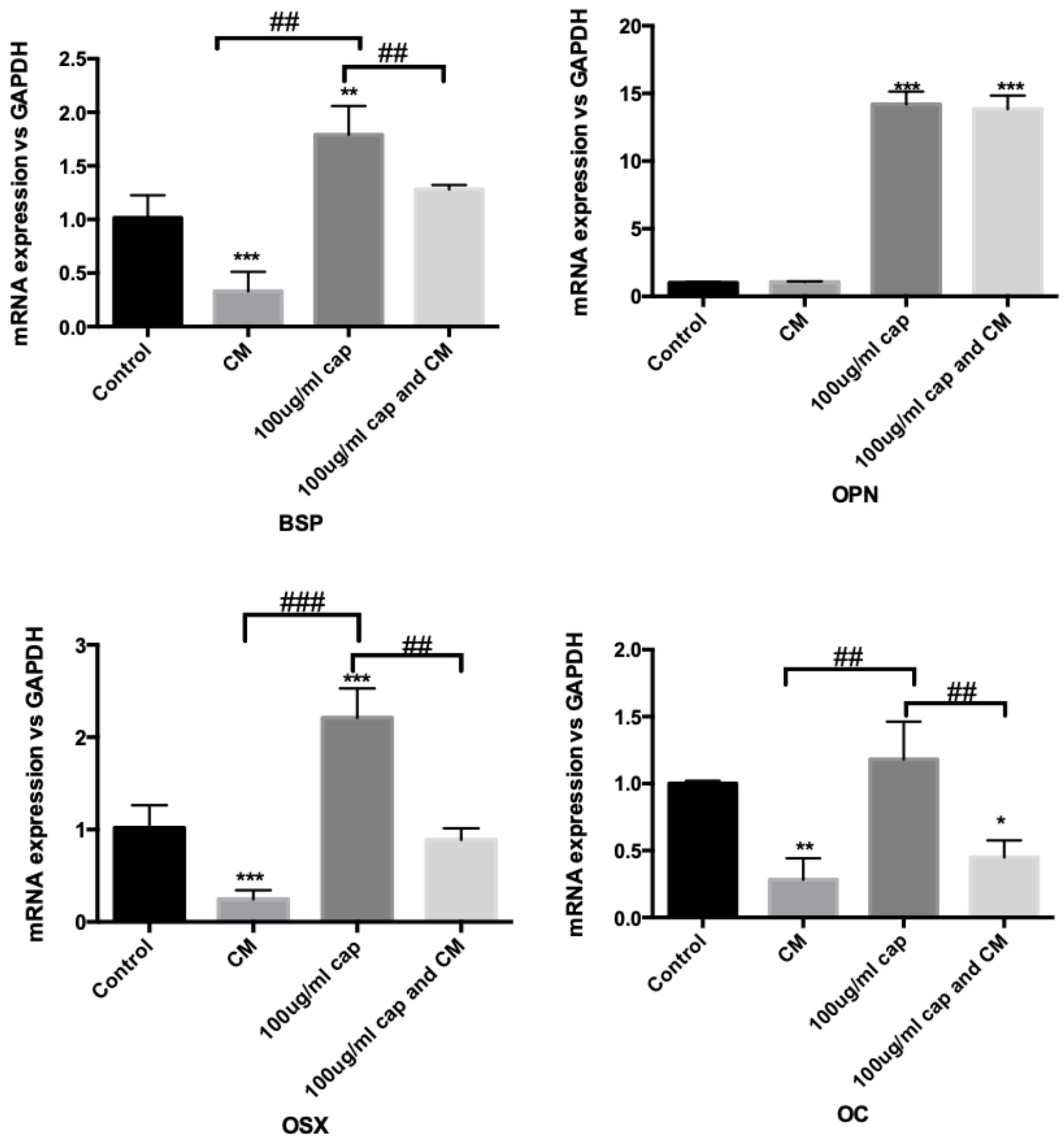

Figure 10

Expression of osteogenic genes. The CM group showed lower levels of BSP, OSX and OC expression than the control group. The CM and $100 \mu \mathrm{g} / \mathrm{ml}$ ACP groups exhibited significantly lower BSP, OSX and OC expression levels than the $100 \mu \mathrm{g} / \mathrm{ml}$ ACP group. OPN expression did not change significantly between the $\mathrm{CM}$ and $100 \mu \mathrm{g} / \mathrm{ml}$ ACP group and the $100 \mu \mathrm{g} / \mathrm{ml}$ ACP group. 